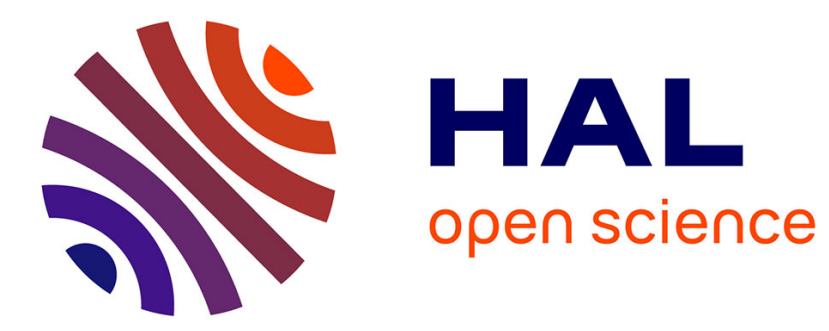

\title{
D-stat culture for studying the metabolic shifts from oxidativemetabolism to lipid accumulation and citric acid production in Yarrowia lipolytica
}

\author{
Abril Ochoa-Estopier, Stéphane Guillouet
}

\section{- To cite this version:}

Abril Ochoa-Estopier, Stéphane Guillouet. D-stat culture for studying the metabolic shifts from oxidativemetabolism to lipid accumulation and citric acid production inYarrowia lipolytica. Journal of Biomedicine and Biotechnology, 2014, 170, pp.35-41. 10.1016/j.jbiotec.2013.11.008 . hal-02637851

\section{HAL Id: hal-02637851 \\ https://hal.inrae.fr/hal-02637851}

Submitted on 28 May 2020

HAL is a multi-disciplinary open access archive for the deposit and dissemination of scientific research documents, whether they are published or not. The documents may come from teaching and research institutions in France or abroad, or from public or private research centers.
L'archive ouverte pluridisciplinaire HAL, est destinée au dépôt et à la diffusion de documents scientifiques de niveau recherche, publiés ou non, émanant des établissements d'enseignement et de recherche français ou étrangers, des laboratoires publics ou privés. 


\title{
D-stat culture for studying the metabolic shifts from oxidative metabolism to lipid accumulation and citric acid production in Yarrowia lipolytica
}

\author{
Abril Ochoa-Estopier ${ }^{\mathrm{a}, \mathrm{b}, \mathrm{c}}$, Stéphane E. Guillouet ${ }^{\mathrm{a}, \mathrm{b}, \mathrm{c}, *}$ \\ a INSA-LISBP, 135 Av. de Rangueil, F-31077 Toulouse, France \\ b INRA, UMR792 Ingénierie des Systèmes Biologiques et des Procédés, F-31400 Toulouse, France \\ c CNRS, UMR5504, F-31400 Toulouse, France
}

\section{A R T I C L E I N F O}

\section{Article history:}

Received 27 August 2013

Received in revised form

12 November 2013

Accepted 14 November 2013

Available online 4 December 2013

\section{Keywords:}

Yarrowia lipolytica

Lipid accumulation

D-stat

Nitrogen limitation

Citric acid production

\begin{abstract}
A B S T R A C T
Lipid accumulation in oleaginous yeasts is triggered by nutrient imbalance in the culture medium between the carbon source in excess and the nitrogen source in limiting concentration. However Yarrowia lipolytica when cultivated on glucose as the sole carbon source, mainly produces citric acid upon nitrogen limitation over lipid accumulation (only 5-10\% triacylglycerol). Therefore for developing bioprocess for the production of triacylglycerol from renewable carbon source as glucose it is of first importance to control this imbalance in order to avoid citric acid production during TAG accumulation.

Using D-stat cultivation system, where the $\mathrm{N} / \mathrm{C}$ was linearly decreased using a constant change rate we were able to identify the $\mathrm{N} / \mathrm{C}$ ratio inducing TAG accumulation $\left(0.085 \mathrm{Nmol} \mathrm{Cmol}^{-1}\right)$ and citric acid $\left(0.021 \mathrm{Nmol} \mathrm{Cmol}^{-1}\right)$. We therefore demonstrated that it was possible to accumulate lipids without excretion citric acid as long as the $\mathrm{N} / \mathrm{C}$ was within this indicated range. Moreover enzyme specific activities measurement during the D-stat indicated that ATP-citrate lyase, malic enzyme and acetyl-coA carboxylase were strongly induced at the onset of lipid accumulation and showed different patterns when citric acid was excreted.

Our results give relevant information for future industrial bioprocess development concerning the production of lipids using renewable carbohydrate substrates as an alternative way to produce synthons for fuel or chemical industry. By controlling the N/C over the fermentation process on glucose $Y$. lipolytica can accumulate lipids without excreting citric acid.
\end{abstract}

(c) 2013 Elsevier B.V. All rights reserved.

\section{Introduction}

Yarrowia lipolytica is one of the most studied "nonconventional" yeasts isolated from oily environments such as polluted soils, raw poultry or dairy products (Sinigaglia et al., 1994; Deak, 2001; Lanciotti et al., 2005; Yalcin and Ucar, 2009), classified as generally recognized as safe (GRAS) by the Food and Drug Administration (FDA, USA). It has become an important industrial microorganism due to the versatility of its metabolism to produce metabolites such as heterologous proteins (Nicaud et al., 2002; Madzak et al., 2004), lipids (Papanikolaou et al., 2003; Bankar et al., 2009; Beopoulos et al., 2009) or citric acid (Papanikolaou et al., 2002; Moeller et al., 2007; Rymowicz et al., 2007).

\footnotetext{
* Corresponding author at: INSA-LISBP, 135 Av. de Rangueil, F-31077 Toulouse, France. Tel.: +33 5615594 47; fax: +33561559400.

E-mail address: stephane.guillouet@insa-toulouse.fr (S.E. Guillouet).
}

Y. lipolytica belongs to the so-called oleaginous yeasts due to its ability to accumulate high amounts of lipid mainly in the form of triacylglycerol (TAG) (Rattray et al., 1975). Y. lipolytica is indeed able to accumulate lipids up to $43 \%$ of its dry mass on glycerol (Papanikolaou and Aggelis, 2002) and over 50\% (w/w) of total lipids, on fatty acids (Papanikolaou et al., 2003).

De novo lipid accumulation in oleaginous yeasts from osidic substrates is triggered by nutrient imbalance in the culture medium between the carbon source (in excess) and the nitrogen source in limiting concentration (although other nutrients can be identically made limiting, such as phosphorus, zinc, iron) (Granger et al., 1993; Ratledge and Wynn, 2002; Fontanille et al., 2012). Contrarily exnovo lipid accumulation (i.e. from oily substrates) approximates to a bioconversion process and therefore is independent to any nutrient imbalance (Papanikolaou and Aggelis, 2011).

Ratledge and Wynn (2002) proposed a general pattern of succession of the metabolic events that take place upon a N-limitation in oleaginous microorganisms (Candida 107 and C. utilis, Rhodotorula glutinis, Mucor circinelloides) leading to lipid accumulation as 
follows: drop in the adenosine monophosphate (AMP) concentration due to the activation of the AMP deaminase, inhibition of the isocitrate dehydrogenase (ICDH) by the low AMP content leading to the accumulation of isocitrate and citrate and then citrate that can be exported from the mitochondrion by a citrate/malate transporter, citrate is cleaved by the ATP-citrate lyase (ACL) into acetyl coenzyme A and oxaloacetate, the acetyl-coA is used for fatty acid synthesis by the acetyl-coA carboxylase (ACC). One characteristic that differentiates oleaginous yeasts from non-oleaginous yeasts is the presence of ATP citrate lyase (ACL) (Holdsworth et al., 1988; Zhang et al., 2007), several authors have also considered that acetyl coA carboxylase (ACC) (Waite and Wakil, 1962; Hasslacher et al., 1993) and malic enzyme (Zhang et al., 2007) are essential for lipid accumulation

Several studies have shown that the metabolic shift in Y. lipolytica is related to a nutrient-limited medium such as nitrogen, phosphorus or magnesium (Gill et al., 1977; Anastassiadis et al., 2002) or to the cultivation conditions such as growth rate, oxygen availability, pH or temperature (Finogenova et al., 1996; Il'chenko et al., 1998; Kamzolova et al., 2003; Moeller et al., 2007). One of the parameter that influences the metabolic shift is the $\mathrm{N} / \mathrm{C}$ ratio (Sattur and Karanth, 1989; Anastassiadis et al., 2005). It is commonly observed in oleaginous yeasts a transient citrate excretion during the first steps of lipogenesis (Boulton and Ratledge, 1983; Evans and Ratledge, 1983a). However Y. lipolytica when cultivated on glucose as the sole carbon source, mainly produces citric acid upon nutrient limitation over lipid accumulation only $5-10 \%$ (w/w) of TAG (Papanikolaou et al., 2006). Therefore it is legitimate to wonder whether Y. lipolytica can accumulate lipids (TAG) without producing citric acid when cultivated on carbohydrate substrates. Developing a bioprocess for the production of triacylglycerol from renewable carbon source as glucose is of first interest as an alternative way to produce synthons for fuel or chemical industry. However the mechanisms controlling the metabolic shift from oxidative to citric acid production over lipid accumulation still need to be elucidated.

Chemostats have been widely used to study microbial metabolism toward numerous nutrient limitations. Alternative continuous cultivation systems were later developed for physiological studies of various microorganisms such as (i) the accelerostat (A-stat) where the dilution rate was linearly increased at a constant change rate (Paalme et al., 1995, 1997)(ii) the D-stat where the dilution rate was kept constant while one of the cultivation parameter (temperature, $\mathrm{N} / \mathrm{C}$ ) was modulated at a constant rate (Kasemets et al., 2003), (iii) auxostat where a cultivation parameter $\left(\mathrm{pH}, \mathrm{pO}_{2}\right.$, $\mathrm{CO}_{2}$ ) was kept constant by controlling the medium feeding pump (Kasemets et al., 2003).

We developed, in this study, a slight variant of D-stat cultivation system, where the $\mathrm{N} / \mathrm{C}$ was linearly decreased using a constant change rate in order to quantify the impact of the modulation of the $\mathrm{N} / \mathrm{C}$ ratio on the metabolism of $Y$. lipolytica grown on glucose as the sole carbon source. This study aimed at investigating the possibility to accumulate TAG without citric acid production in this yeast on glucose.

\section{Materials and methods}

\subsection{Microorganism, media and growth conditions}

The strain used in this study was Y. lipolytica W29 obtained from the Laboratoire Microbiologie et Génétique Moléculaire, INRA, (Paris-Grignon, France). The strain was maintained on YPD/glucose agar medium containing $10 \mathrm{gl}^{-1}$ yeast extract, $20 \mathrm{gl}^{-1}$ bactopeptone, $20 \mathrm{~g} \mathrm{l}^{-1}$ glucose and $20 \mathrm{gl}^{-1}$ agar. Plates were stored at $4{ }^{\circ} \mathrm{C}$. For preparation of glycerol stocks (for cryopreservation of the cells), pure sterile glycerol was added to the culture broth to reach a final glycerol concentration of $30 \%(\mathrm{v} / \mathrm{v})$. This cell suspension (glycerol stocks) was then stored at $-80^{\circ} \mathrm{C}$.

Precultivations for chemostat were carried out on a 5-ml tube of YPD medium at $28^{\circ} \mathrm{C}$ for $16 \mathrm{~h}$ at $100 \mathrm{rpm}$. The culture in growth phase was transferred into a 1-1 Erlenmeyer flask containing $170 \mathrm{ml}$ of mineral medium at $\mathrm{pH} 5.6$ prepared as follows (all compounds are expressed in $\left.\mathrm{gl}^{-1}\right)$ : $\left(\mathrm{NH}_{4}\right)_{2} \mathrm{SO}_{4}, 3.5 ; \mathrm{KH}_{2} \mathrm{PO}_{4}, 6 ; \mathrm{MgSO}_{4}$, 2; EDTA, 0.0375; $\mathrm{ZnSO}_{4} \cdot 7 \mathrm{H}_{2} \mathrm{O}, 0.0281 ; \mathrm{MnCl}_{2} \cdot 4 \mathrm{H}_{2} \mathrm{O}, 0.0025$; $\mathrm{CoCl}_{2} \cdot 6 \mathrm{H}_{2} \mathrm{O}, 0.00075 ; \mathrm{CuSO}_{4} \cdot 5 \mathrm{H}_{2} \mathrm{O}, 0.00075 ; \mathrm{Na}_{2} \mathrm{MoSO}_{4} \cdot 2 \mathrm{H}_{2} \mathrm{O}$, $0.00005 ; \mathrm{CaCl}_{2} \cdot 2 \mathrm{H}_{2} \mathrm{O}, 0.0125 ; \mathrm{FeSO}_{4} \cdot 7 \mathrm{H}_{2} \mathrm{O}, 0.00875 ; \mathrm{H}_{3} \mathrm{BO}_{3}$, 0.0025; D-biotin, 0.00025; D-L-panthotenic acid, 0.001; nicotinic acid, 0.001; my0-inositol, 0.00625; thiamin, 0.001; pyridoxine, 0.001 ; para-aminobenzoic acid, 0.0002 . Glucose was added to a final concentration of $18 \mathrm{~g} \mathrm{l}^{-1}$ with chloramphenicol at $10 \mathrm{mg} \mathrm{l}^{-1}$. After $16 \mathrm{~h}$ of growth at $28^{\circ} \mathrm{C}$ and $100 \mathrm{rpm}, 170 \mathrm{ml}$ of the broth were used to inoculate 1.71 of the same mineral medium in a 3-1 bioreactor.

\subsection{Chemicals used}

The chemicals glucose, salts, oligo-elements (Carlo Erba) and EDTA (Qbiogène), orthophosphoric acid were provided by VWR, the vitamins by Sigma. All products had the highest analytical grade available.

\subsection{Chemostat and D-stat cultivation in bioreactor}

Chemostat and D-stat experiments were performed in a 3-1 stirred tank bioreactor with a working volume of 1.51 using the Biostat B. Braun Biotech International (Sartorius AG, Germany) with the acquisition software MFCS/win 2.0. The temperature was regulated at $28^{\circ} \mathrm{C}$ and the $\mathrm{pH}$ at 5.6 by the in-line addition of $5 \mathrm{M} \mathrm{NaOH}$. The fermentation started in batch under full aerobic conditions. The dissolved oxygen was maintained above $20 \%$ of saturation by modulating the air flow rate or the stirring rate in order to avoid oxygen limitation. $11 \mathrm{~h}$ after inoculation, when the glucose was totally consumed, continuous cultivation was started. Foaming was controlled by periodically adding sterile antifoaming agent (polypropylene glycol, Aldrich) via a peristaltic pump.

For chemostat cultivation, the bioreactor was continuously fed with the mineral medium (except $\left.\left(\mathrm{NH}_{4}\right)_{2} \mathrm{SO}_{4}\right)$ supplemented with $23 \mathrm{~g} \mathrm{l}^{-1}$ glucose at $0.108 \mathrm{lh}^{-1}$. The bioreactor was fed with a second reservoir containing $60 \mathrm{~g} \mathrm{l}^{-1}\left(\mathrm{NH}_{4}\right)_{2} \mathrm{SO}_{4}$ at $0.0117 \mathrm{l} \mathrm{h}^{-1}$ corresponding to a $\mathrm{N} / \mathrm{C}$ ratio of $0.1285 \mathrm{molN} \mathrm{Cmol}^{-1}$. The working dilution rate was $0.08 \mathrm{~h}^{-1}$.

\subsection{D-stat feeding strategy}

When the steady state was reached after 5 residence times $(7=1 / D)$, the D-stat was set up. The feeding rate of the mineral medium supplemented with glucose was maintained constant at $0.1081 \mathrm{~h}^{-1}$ while the $\left(\mathrm{NH}_{4}\right)_{2} \mathrm{SO}_{4}$ feeding rate followed a linear and smooth decrease from $0.01171 \mathrm{~h}^{-1}$ to $0.00031 \mathrm{~h}^{-1}$ for $50 \mathrm{~h}$ corresponding to a decrease in the $\mathrm{N} / \mathrm{C}$ ratio from 0.1285 to $0.0033 \mathrm{molN} \mathrm{Cmol}^{-1}$ (mole of nitrogen per mole of carbon). All other parameters were maintained unchanged.

\subsection{Off gas analysis}

The inlet and outlet gas compositions in carbon dioxide $\left(\mathrm{CO}_{2}\right)$ and oxygen $\left(\mathrm{O}_{2}\right)$ were measured by a fermentation gas monitor system (LumaSense technologies Europe). The system combines a multipoint sampler 1309 with a gas analyzer (INNOVA 1313). Gas analysis was performed every minute during the whole experiment. $\mathrm{CO}_{2}$ production rate $\left(r_{\mathrm{CO}_{2}}\right)$ and $\mathrm{O}_{2}$ consumption rate $\left(r_{\mathrm{O}_{2}}\right)$ 
were calculated as described by Poilpre et al. (2002). The respiratory quotient (RQ) was calculated as the molar ratio between $r_{\mathrm{CO}_{2}}$ and $r_{\mathrm{O}_{2}}$.

\subsection{Determination of biomass}

Yeast growth was evaluated by spectrophotometric measurements at $620 \mathrm{~nm}$ in a spectrophotometer (Biochrom Libra S4, UK). Growth rates were determined based on time-courses of optical density $\left(\mathrm{OD}_{620 \mathrm{~nm}}\right) . \mathrm{OD}_{620 \mathrm{~nm}}$ was calibrated against dry cell weight measurements. The biomass formula used to convert cell dry weight into molar carbon concentration was $\mathrm{CH}_{1.744} \mathrm{O}_{0.451} \mathrm{~N}_{0.132}$ for a molecular weight of $24.67 \mathrm{~g} \mathrm{Cmol}^{-1}$ (Cescut, 2009).

\subsection{Metabolite analysis}

The culture supernatants were analyzed by High Performance Liquid Chromatography (DIONEX Ultimate 3000, USA) using an Aminex HPX-87 $\mathrm{H}^{+}$column (Bio-RAd, US) and the following conditions: a temperature of $50{ }^{\circ} \mathrm{C}$ with $5 \mathrm{mM} \mathrm{H}_{2} \mathrm{SO}_{4}$ as eluant (flow rate of $0.5 \mathrm{ml} \mathrm{min}^{-1}$ ) and a dual detection (IR and UV at $210 \mathrm{~nm}$ ). Culture supernatant was obtained by centrifuging (MiniSpin ependorf, USA) the fermentation culture in Eppendorf tubes at 13,000 rpm for $3 \mathrm{~min}$. The supernatant was filtered on Minisart filters $0.45 \mu \mathrm{m}$ pore-size diameter polyamide membranes (Sartorius AG, Germany). The metabolites searched for detections and quantification were glucose, citrate, isocitrate, alpha-ketoglutarate, pyruvate, malate, succinate, fumarate, lactate and acetate.

The quantification of lipids was carried out by digestion as described by Browse et al. (1986). $20 \mathrm{mg}$ of lyophilized cells were added to $1 \mathrm{ml}$ of methanol solution containing $25 \mathrm{ml} \mathrm{l}^{-1}$ of sulfuric acid (95\%) and internal standard (C9:0). The mix in sealed tubes was placed in a $80^{\circ} \mathrm{C}$ bath for $90 \mathrm{~min}$. After cooling, $450 \mu \mathrm{l}$ hexane and $1.5 \mathrm{~mL}$ water were added and vortexed. The lipidic phase was then sampled and the composition was analyzed by gas chromatography as mentioned in Cescut et al. (2011). Lipid quantification was also performed by epifluorescence after staining the cells with Bodipy 493/503 in a Microplate reader (Synergy HT, Biotek, USA) as follows: the pellets were washed 3 times with $\mathrm{PBS}$ buffer solution (in $\mathrm{gl}^{-1}, \mathrm{NaCl}, 8 ; \mathrm{Na}_{2} \mathrm{HPO}_{4}, 1.15 ; \mathrm{KCl}, 0.2 ; \mathrm{KH}_{2} \mathrm{PO}_{4}, 0.2 ; \mathrm{pH}$ at 6.9-7.1) at $4{ }^{\circ} \mathrm{C}$ and resuspended in the same buffer solution to a $\mathrm{OD}_{620 \mathrm{~nm}}$ of $0.5 ; 1 \mathrm{ml}$ of the cell suspension was mixed with $10 \mu \mathrm{l}$ of Bodipy $493 / 503\left(100 \mu \mathrm{g} \mathrm{ml}^{-1}\right.$ in DMSO) and incubated $5 \mathrm{~min}$ at $4{ }^{\circ} \mathrm{C}$; the mixture was then centrifuged 3 min at 13,000 rpm and resuspended into $1 \mathrm{ml}$ of PBS buffer solution; $200 \mu \mathrm{l}$ of this cell suspension were placed in a 96-well Nunclon ${ }^{\mathrm{TM}} \Delta$ surface Microplate and read at $528 \mathrm{~nm}$ with an excitation wavelength value of $428 \mathrm{~nm}$. The measurements were repeated 5 times showing a standard deviation lower than $5 \%$.

The quantification of residual ammonium in the medium was determined with an Orion ammonium probe (ORION research INC., Boston, USA) and a voltmeter (ORION pH/ISE Meter, USA) as follows: $5 \mathrm{ml}$ of culture broth were filtered on $0.45 \mu \mathrm{m}$ poresize diameter polyamide membrane (Sartorius AG, Germany) and mixed with $200 \mu \mathrm{l}$ of ISA buffer solution (Ionic Strength Adjustor: $\mathrm{NaOH}, 5 \mathrm{moll}^{-1}$; disodium EDTA, $0.05 \mathrm{moll}^{-1}$ and methanol $1 \mathrm{gl}^{-1}$ ). The concentration of $\mathrm{NH}_{4}$ was determined with a calibration curve correlating the $\mathrm{mV}$ and the $\mathrm{NH}_{4}$ concentration in a range of $10^{-1}-10^{-4} \mathrm{moll}^{-1} \mathrm{NH}_{4} \mathrm{Cl}$.

In all cultivations, considering the extracellular metabolites quantification, the biomass and the composition of off-gas, carbon and degree of reduction balances closed to $100 \pm 5 \%$.

\subsection{Enzyme assays}

Cells were harvested by centrifuging at $4000 \mathrm{rpm}$ for $4 \mathrm{~min}$ at $4{ }^{\circ} \mathrm{C}$ and washed four times by resuspension in iced water. Around
$50 \mathrm{mg}$ of dry cell weight were resuspended in $1000 \mu \mathrm{l}$ of extraction buffer (in mM, Tris/HCl, 50; KCl, 100; EDTA 1; DTT, 1; Benzamidine $\mathrm{HCl}, 1$; final $\mathrm{pH} 7.5$ ). Yeast cells were disrupted by vortexing the cell suspension after addition of $1 \mathrm{~g}$ of iced glass beads $(d=0.2-0.5 \mathrm{~mm}$, Sigma) for 10 cycles of $30 \mathrm{~s}$ vortex and $30 \mathrm{~s}$ in ice. Cells debris were removed by centrifuging the suspension at $4000 \mathrm{rpm}$ for $40 \mathrm{~min}$ at $4{ }^{\circ} \mathrm{C}$. Cell breakage efficiency was checked by quantifying the protein content in the cell-free extracts following the Bio-Rad Protein Assay kit procedure (Bio-Rad, France).

All the enzymatic assays were carried out at $30^{\circ} \mathrm{C}$. Activities of the ATP citrate lyase (E.C. 2.3.3.8), acetyl CoA carboxylase (E.C. 6.4.1.2), malate dehydrogenase (E.C. 1.1.1.37), and malic enzyme were determined as described by (Srere, 1962; Mishina et al., 1971; Ochoa, 1955a,b) respectively. Specific activities were expressed in milliunits per milligrams of total protein ( $\mathrm{mU} \mathrm{mg} \operatorname{prot}^{-1}$ ).

\section{Results and discussion}

\subsection{Kinetics parameters during full oxidative metabolism of $Y$. lipolytica}

Y. lipolytica was grown on glucose as the sole carbon source in the mineral medium under full aeration condition in batch and chemostat bioreactor. A maximal growth rate $\left(\mu_{\max }\right.$ calculated by linearization of the data in the exponential growth phase) of $0.27 \mathrm{~h}^{-1}$ was obtained under batch cultivation. This value is in good agreement with other $Y$. lipolytica strains grown on glucose (Deive et al., 2010; Workman et al., 2013). The respiratory quotient (RQ) was constant at $1.04 \pm 0.02 \mathrm{~h}^{-1}$ which is characteristic to a fully oxidative growth. The biomass yield on glucose $\left(Y_{x / s}\right)$ was then $0.49 \pm 0.012 \mathrm{~g}_{\mathrm{DCW}} \mathrm{g}_{\text {glucose }}{ }^{-1}$. This yield was higher than the one reported by Papanikolaou and Aggelis (2002) and Papanikolaou et al. (2006) $\left(Y_{x / s}\right.$ of 0.20 and $0.45 \mathrm{~g}_{\mathrm{DCW}} \mathrm{g}_{\text {glucose }}{ }^{-1}$, respectively), probably because those experiments were carried out in flasks where the oxygen transfer could be a limiting factor for biomass production.

Chemostat cultivation was carried out under glucose limitation at a dilution rate of $0.08 \mathrm{~h}^{-1}$. At steady state, no residual glucose was detected in the medium suggesting a complete uptake of the glucose and no metabolites were detected in the broth. The respiratory quotient (RQ) was $1.04 \pm 0.02 \mathrm{~h}^{-1}$ confirming the full oxidative metabolism (Fig. 1). A maximal biomass concentration of $9.7 \mathrm{~g}_{\mathrm{DCW}} \mathrm{l}^{-1}$ was obtained and remained constant during the whole chemostat cultivation corresponding to a $Y_{x / s}$ of $0.47 \pm 0.01 \mathrm{~g}_{\mathrm{DCW}} \mathrm{g}_{\text {glucose }}{ }^{-1}$.

\subsection{Impact of the $\mathrm{N} / \mathrm{C}$ ratio on the lipid accumulation and citric acid production in Y. lipolytica from glucose as sole carbon source}

Under glucose-limited chemostat when $\mathrm{N} / \mathrm{C}$ ratio was set at $0.1285 \mathrm{molN} \mathrm{Cmol}^{-1}$, neither accumulation of lipids nor extracellular citric acid was detected (Fig. 1). Lipids were accounted for $12 \%$ $(\mathrm{w} / \mathrm{w})$ of the dried biomass, reportedly the amount for constitutive lipid. Photographs of labeled cells with Bodipy 493/503 fluorescent dye confirmed the absence of lipid accumulation at steady-state of the glucose-limited chemostat.

In order to investigate the impact of the $\mathrm{N} / \mathrm{C}$ ratio on the metabolism of $Y$. lipolytica, a slight variant of a D-stat was set once the steady-state of the chemostat was reached. The feeding rate of the Nitrogen source $\left(\left(\mathrm{NH}_{4}\right)_{2} \mathrm{SO}_{4}\right.$ solution) was gradually decreased from $10.6 \mathrm{mmolN} \mathrm{h}^{-1}$ to $2.7 \mathrm{mmolN} \mathrm{h}^{-1}$ in $50 \mathrm{~h}$ at a constant change rate $a_{\mathrm{N} / \mathrm{C}}=-0.0025 \mathrm{Nmol} \mathrm{Cmol}^{-1} \mathrm{~h}^{-1}$. The D-stat allowed us to modulate the $\mathrm{N} / \mathrm{C}$ ratio from of 0.1285 to $0.0033 \mathrm{Nmol} \mathrm{Cmol}^{-1}$ (Fig. 2). The concomitant decrease in the dilution rate was from 0.08 to $0.072 \mathrm{~h}^{-1}$ in $50 \mathrm{~h}$ ( $8 \%$ decrease overall). 


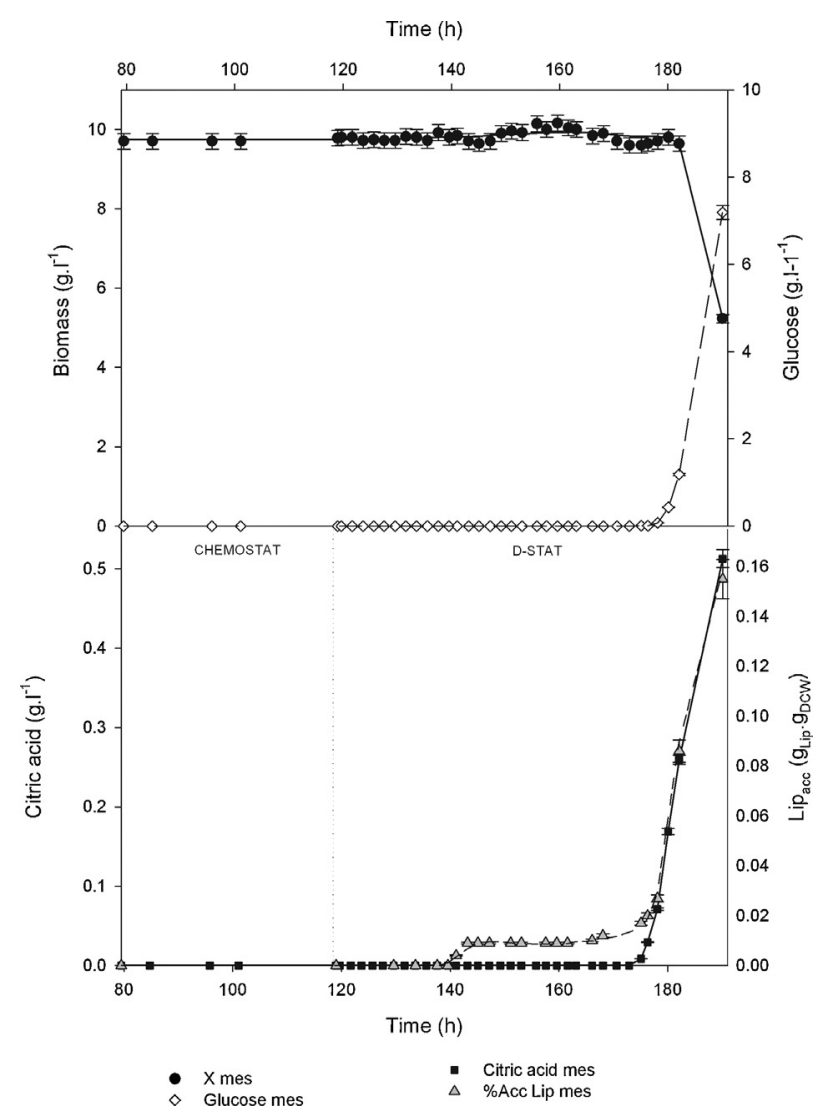

Fig. 1. Evolution of the concentrations of glucose, biomass, citric acid and accumulated lipids during chemostat and D-stat of Y. lipolytica W29. All sampling were performed in triplicate. Data are presented as means \pm standard deviation $(n=3)$.

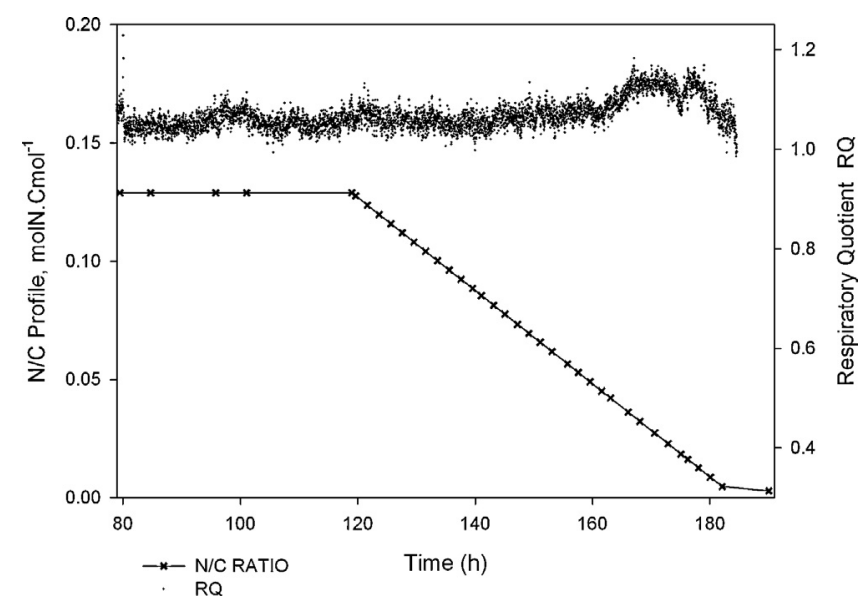

Fig. 2. Evolution of respiratory quotient and N/C ratio during chemostat and D-stat of Y. lipolytica W29.

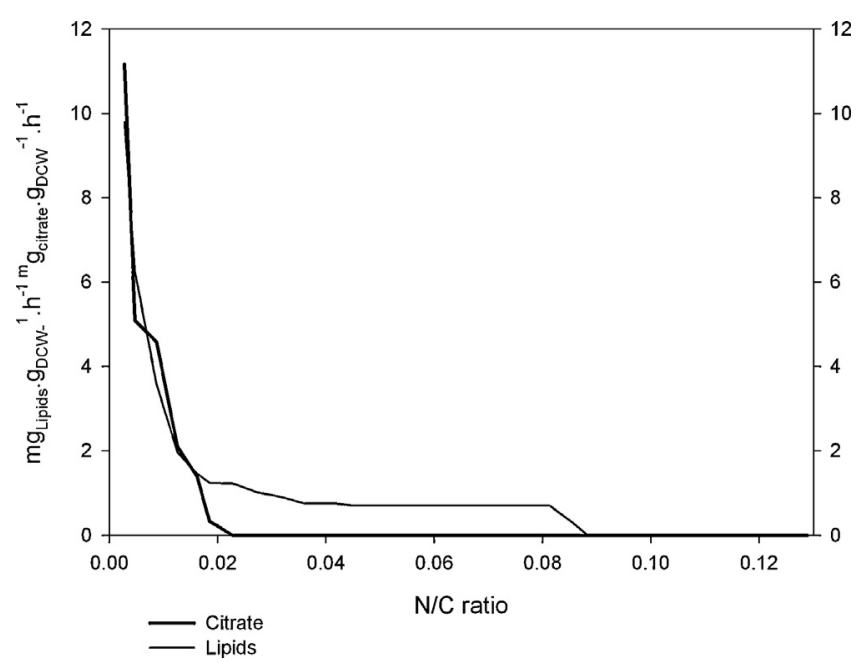

Fig. 4. Evolution of the specific rates of citric acid production and TAG accumulation as a function of N/C ratio during chemostat and D-stat of Y. lipolytica W29.

The on-line determination of the respiratory quotient during the D-stat showed an increase in its value after $140 \mathrm{~h}$ from $1.04 \pm 0.02 \mathrm{~h}^{-1}$ to a maximal value of $1.12 \pm 0.02 \mathrm{~h}^{-1}$ reached at $165 \mathrm{~h}$ (Fig. 2). This increase could be explained by an accumulation of compounds more reduced than the glucose into the cells, such as lipids. This was confirmed by cellular lipid content measurement (Fig. 1) and by Bodipy 493/503 cell staining (Fig. 3b-e). Therefore $Y$. lipolytica accumulated lipids after $\mathrm{N} / \mathrm{C}$ ratio reached a value of $0.085 \mathrm{Nmol} \mathrm{Cmol}^{-1}$, however the lipid accumulation was low around $5 \%(\mathrm{w} / \mathrm{w})$.

No citric acid production was detected before $174 \mathrm{~h}$ of culture time (Fig. 1). Then the RQ started to decrease suggesting a citric acid production because citric acid is a more oxidized compound than glucose (Fig. 2). Excretion of citric acid was confirmed by HPLC measurement (Fig. 1). The $\mathrm{N} / \mathrm{C}$ ratio for citric acid production was then evaluated equal to $0.021 \mathrm{Nmol} \mathrm{Cmol}^{-1}$. Below this $\mathrm{N} / \mathrm{C}$ ratio, Y. lipolytica accumulated further more lipids (up to $16 \%, \mathrm{w} / \mathrm{w}$ ) concomitantly with citric acid production (Fig. 3e).

\subsection{Impact of the $N / C$ ratio on the kinetic parameters in $Y$. lipolytica}

The decrease in the nitrogen supply caused the transition from a carbon limitation condition to a carbon and nitrogen limitation condition and a concomitant decrease in the specific growth rate was observed from 0.08 to $0.072 \mathrm{~h}^{-1}$. Fig. 4 clearly shows that $Y$. lipolytica had the ability to accumulate lipids without producing citric acid within a N/C range of $0.021-0.084 \mathrm{molN} \mathrm{Cmol}^{-1}$ where the specific rate of lipid accumulation slightly varied between 0.74 and $1.26 \mathrm{mg}_{\text {lip }} \mathrm{g}_{\mathrm{DCW}}{ }^{-1} \mathrm{~h}^{-1}$. Above the critical $\mathrm{N} / \mathrm{C}$ ratio of $0.021 \mathrm{molN} \mathrm{Cmol}^{-1}$, the specific rate of lipid accumulation strongly increased with a maximal value of $12 \mathrm{mg}_{\text {lip }} \mathrm{g}_{\mathrm{DCW}}{ }^{-1} \mathrm{~h}^{-1}$ concomitantly with the increased production of citric acid.

The specific lipid production rate decrease could be linked to the nitrogen depletion or an active regulation system control. On

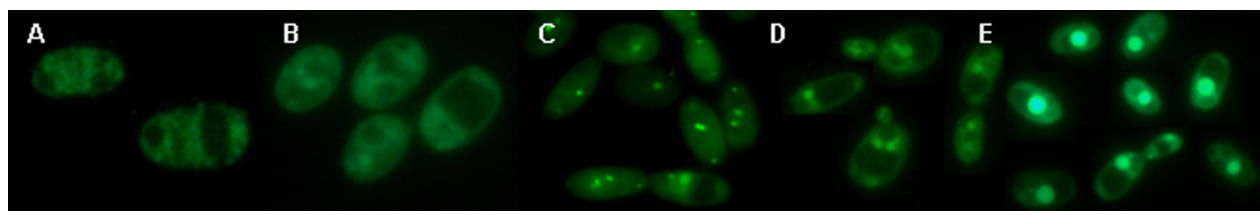

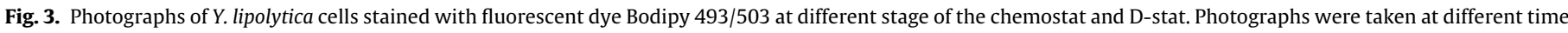
points during the chemostat and D-stat: A: 100h; B: 131h; C: 145h; D: 166h; E: $185 \mathrm{~h}$. 
the one hand, protein turnover needs a constant nitrogen supply. Under nitrogen limitation, autophagy could take place according to Kasemets et al. (2003), Onodera and Ohsumi (2005) and Kohda et al. (2007). Autophagy consists in the degradation of cytoplasmic components including a significant amount of proteins and rRNA. This loss of cell machinery implies an increase of cell maintenance and a decrease of conversion yields. On the other hand, lipid accumulation induces a macromolecular composition upheaval which could impact intracellular chemical and physical properties such as $\mathrm{pH}$, osmotic pressure, steric hindrance. However Tai and Stephanopoulos (2013) showed lately that an increase in the capacity of accumulating TAG in Y. lipolytica was possible up to $60 \%$ (w/w) by overexpressing an acetyl CoA carboxylase (ACC1) and a diacylglycerol acyltransferase (DGA1). These results eliminate the assumption of regulatory system controlling the steric hindrance due to accumulation of high amount of TAGs.

\subsection{Impact of the $\mathrm{N} / \mathrm{C}$ ratio on specific enzyme activities}

The impact of the $\mathrm{N} / \mathrm{C}$ ratio was investigated at the protein level by measuring some specific enzyme activities. The enzymatic activities of ATP citrate lyase (ACL), acetyl CoA carboxylase (ACC), malic enzyme (ME) and malate dehydrogenase (MD) were chosen based on their involvement at the metabolic carrefour of the citric acid. The profiles during the chemostat and D-stat are shown in Fig. 5. A pronounced increased in the specific activities of ACL, ACC and ME was observed during the D-stat, while the activity of MD very slightly increased over the course of the D-stat.

The profile of the ACL specific activity increased when the N/C ratio reached a value of $0.084 \mathrm{molN} \mathrm{Cmol}^{-1}(140 \mathrm{~h})$ corresponding to the onset of the lipid accumulation. ACL supplies the acetyl CoA units needed for the synthesis of lipids (Srere and Lipmann, 1953). Increase in the ACL specific activity was reported in Candida curvata in batch and continuous culture during lipid accumulation (Evans and Ratledge, 1983a,b). However no significant variation in specific ACL activity was observed during lipogenesis in continuous culture in Lipomyces starkeyi (Boulton and Ratledge, 1983). Here the specific activity of ACL increased 5-fold during the phase of lipid accumulation in Y. lipolytica. The activity of ACL was maximal during lipid accumulation and sharply decreased with the onset of citric acid excretion at $170 \mathrm{~h}$. The strong decrease in the ACL at the period where the specific rate of lipid accumulation was the highest could indicate that ACL was not the limiting step for lipid accumulation. This is reinforced by the fact that overexpression of the single ACC1, coding for an acetyl CoA carboxylase, led to a 2-fold increase in the lipid accumulation in Y. lipolytica (Tai and Stephanopoulos, 2013).

Acetyl CoA carboxylase (ACC) has been reported by many authors to be the key enzyme for lipid accumulation (Volpe and Vagelos, 1976; Davis et al., 2000). Very recently overexpression of ACC1 in Y. lipolytica led to an increase in lipid accumulation from $8.7 \%$ to $17.9 \%$ (Tai and Stephanopoulos, 2013). In our study, ACC showed its maximal specific activity during lipid accumulation and maintain this activity even after excretion of citric acid in the medium. This observation could indicate that ACC may be also important to maintain lipid accumulation at a high rate.

The activity of malate dehydrogenases (cytosolic, mitochondrial and peroxysomial isoforms were not distinguished in our assay) showed a weak induction of its synthesis at the onset of lipid accumulation and a decrease during citric acid production which is in agreement with the results obtained by different authors (Mullinax et al., 1982; Fahien et al., 1988). One of the roles for the cytosolic isoform could be to participate to a NADPH supplying metabolic cycle composed by the MDH, the ME and the pyruvate carboxylase (Ratledge and Wynn, 2002).

The profile of the malic enzyme (ME) specific activity showed significant increase after $165 \mathrm{~h}$ when the specific lipid accumulation

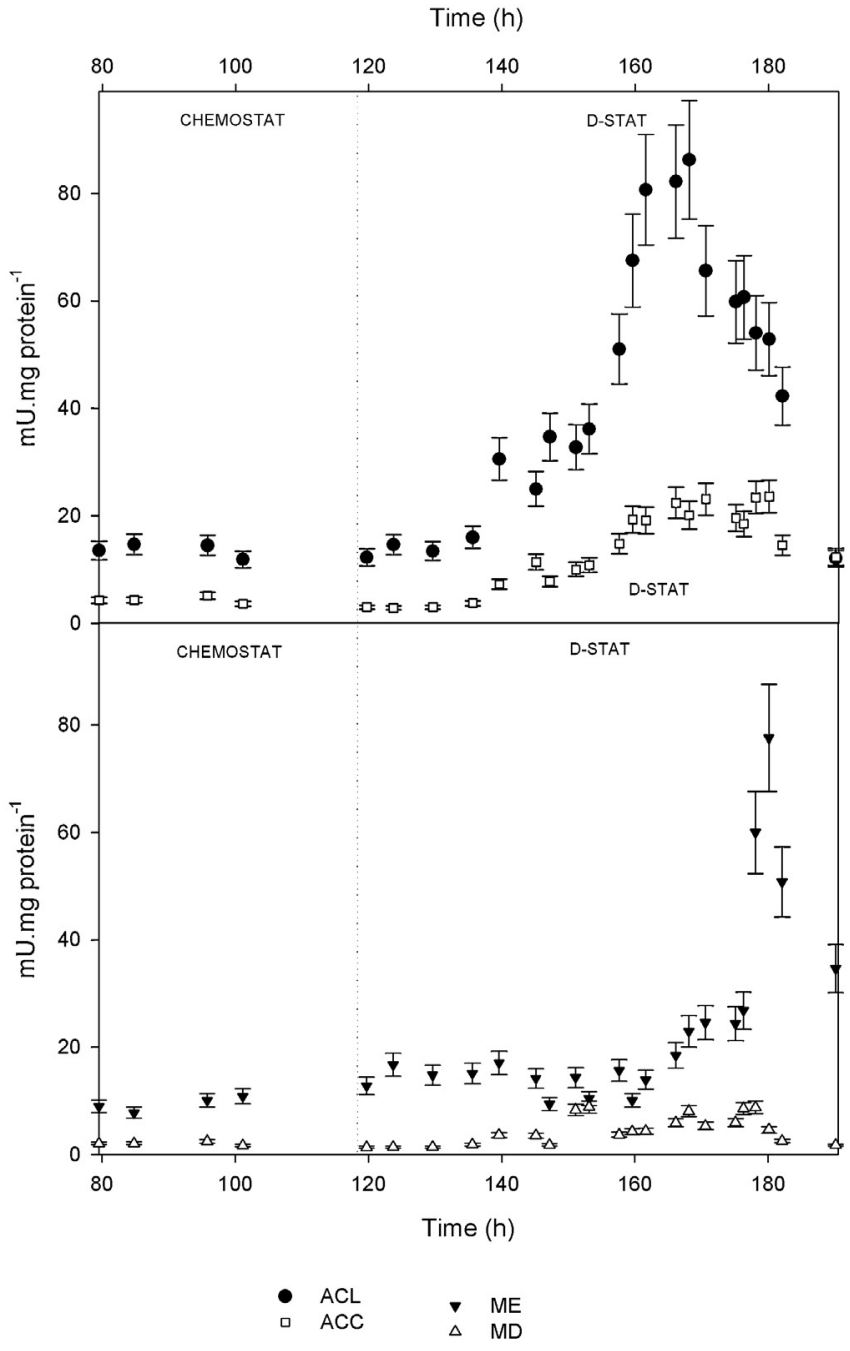

Fig. 5. Evolution of the specific enzyme activities during chemostat and D-stat of Y. lipolytica W29. Enzymes: ACL, ATP citrate lyase; ACC, acetyl-CoA carboxylase; $\mathrm{EM}$, malic enzyme; MD, malate dehydrogenase. The dashed line corresponds to the beginning of the D-stat. All sampling were performed in triplicate. Data are presented as means \pm standard deviation $(n=3)$.

rate strongly increased. The amount of ME was maximal at $180 \mathrm{~h}$ when the lipid accumulation exhibited its highest specific rate. Our data pointed out a basal ME abundance able to support low lipid accumulation rate (slightly over $1 \mathrm{mg}_{\text {lip }} \mathrm{g}_{\mathrm{DCW}}{ }^{-1} \mathrm{~h}^{-1}$ ). The importance of the malic enzyme in the process of lipid accumulation is not completely elucidated so far. In oleaginous fungi such as $M$. circinelloides and Aspergillus nidulans, the inhibition or deletion of ME resulted in a strong decrease in lipid accumulation (Wynn et al., 1997; Wynn and Ratledge, 1997) and the overexpression of the ME in $M$. circinelloides resulted in a 2.5 -fold increase in lipid accumulation (Zhang et al., 2007). However in Y. lipolytica, the native ME single overexpression (unpublished data referenced in Beopoulos et al., 2009) and a heterologous NADP-dependent malic enzyme (Zhang et al., 2013) did not increase the lipid content. Therefore the supply of NADPH by the MDH-ME cycle may not be crucial for lipid content but it could be important to sustain high lipid accumulation rate.

\section{Conclusions}

The experiments carried out using chemostat and D-stat cultivation techniques with a smooth controlled change on a cultivation 
parameter showed the potential of these techniques in the determination of the critical parameters and events involved in the metabolic shift from oxidative metabolism to lipid accumulation and citric acid production in Y. lipolytica on glucose. Our results showed that one of the most important factors in the metabolic transition is the N/C ratio which was identified to be 0.085 and $0.021 \mathrm{molN} \mathrm{Cmol}^{-1}$ for lipid accumulation and citric acid production, respectively. The evolution of the specific activity of ACL, $\mathrm{ME}$ and ACC may indicate their importance in the onset of the metabolic shifts studied here. Further studies will be performed in order to examine the behavior of $Y$. lipolytica strains genetically modified for these genes during the transition of this metabolic shift. Our results give relevant informations for future industrial bioprocess development concerning the production of lipids using carbohydrate substrates since we demonstrated the possibility to accumulate TAG without producing citric acid from glucose in $Y$. lipolytica.

\section{Conflict of interest}

The authors have no conflict of interest to declare.

\section{Acknowledgments}

This work was partially supported by the National Agency of Research (ANR, Project Lipicaero, France) and by a Doctoral grant from the National Council of Science and Technology, (Conacyt, Mexico). We thank Dr. Jean-Marc Nicaud for helpful discussions.

\section{References}

Anastassiadis, S., Aivasidis, A., Wandrey, C., 2002. Citric acid production by Candida strains under intracellular nitrogen limitation. Applied Microbiology and Biotechnology 60 (1/2), 81-87.

Anastassiadis, S., Wandrey, C., Rehm, H.J., 2005. Continuous citric acid fermentation by Candida oleophila under nitrogen limitation at constant $\mathrm{C} / \mathrm{N}$ ratio. World Journal of Microbiology and Biotechnology 21 (5), 695-705.

Bankar, A.V., Kumar, A.R., Zinjarde, S.S., 2009. Environmental and industrial applications of Yarrowia lipolytica. Applied Microbiology and Biotechnology 84 (5), $847-865$.

Beopoulos, A., Cescut, J., Haddouche, R., Uribelarrea, J.L., Molina-Jouve, C., Nicaud, J.M., 2009. Yarrowia lipolytica as a model for bio-oil production. Progress in Lipid Research 48 (6), 375-387.

Boulton, C.A., Ratledge, C., 1983. Use of transition studies in continuous cultures of Lipomyces starkeyi, an oleaginous yeast, to investigate the physiology of lipid accumulation. Microbiology 129 (9), 2871-2876.

Browse, J., Warwick, N., Somerville, C.R., Slack, C.R., 1986. Fluxes through the prokaryotic and eukaryotic pathways of lipid-synthesis in the 16:3 plant Arabidopsis thaliana. Biochemical Journal 235 (1), 25-31.

Cescut, J., (PhD Thesis) 2009. Accumulation d'acylglycérols par des espèces levuriennes à usage carburant aéronautique: physiologie et performance de procedés. Université de Toulouse.

Cescut, J., Severac, E., Molina-Jouve, C., Uribelarrea, J.L., 2011. Optimizing pressurized liquid extraction of microbial lipids using the response surface method. Journal of Chromatography A 1218 (3), 373-379.

Davis, M.S., Solbiati, J., Cronan, J.E., 2000. Overproduction of acetyl-CoA carboxylase activity increases the rate of fatty acid biosynthesis in Escherichia coli. Journal of Biological Chemistry 275 (37), 28593-28598.

Deak, T., 2001. Identification of yeasts isolated from poultry meat. Acta Biologica Hungarica 52 (2/3), 195-200

Deive, F.J., Angeles Sanromán, M., Longo, M.A., 2010. A comprehensive study of lipase production by Yarrowia lipolytica CECT 1240 (ATCC 18942): from shake flask to continuous bioreactor. Journal of Chemical Technology and Biotechnology 85 (2), 258-266.

Evans, C.T., Ratledge, C., 1983a. A comparison of the oleaginous yeast, Candida curvata, grown on different carbon sources in continuous and batch culture. Lipids 18 (9), 623-629.

Evans, C.T., Ratledge, C., 1983b. Biochemical activities during lipid accumulation in Candida curvata. Lipids 18 (9), 630-635.

Fahien, L.A., Kmiotek, E.H., Macdonald, M.J., Fibich, B., Mandic, M., 1988. Regulation of malate dehydrogenase activity by glutamate, citrate, alpha-ketoglutarate and multienzyme interaction. Journal of Biological Chemistry 263 (22), 10687-10697.

Finogenova, T.V., Kamzolova, S.V., Shishkanova, N.V., Ilchenko, A.P., Dedyukhina, E.G., 1996. Influence of the specific growth rate and zinc ions on the synthesis of citric and isocitric acids and on the biomass composition of Yarrowia lipolytica N 1 yeast. Applied Biochemistry and Microbiology 32 (1), 30-34.

Fontanille, P., kumar, V., Christophe, G., Nouaille, R., Larroche, C., 2012. Bioconversion of volatile fatty acids into lipids by the oleaginous yeast Yarrowia lipolytica. Bioresource technology 114, 443-449.

Gill, C.O., Hall, M.J., Ratledge, C., 1977. Lipid-accumulation in an oleaginous yeas (Candida 107) growing on glucose in single-stage continuous culture. Applied and Environmental Microbiology 33 (2), 231-239.

Granger, L.M., Perlot, P., Goma, G., Pareilleux, A., 1993. Effect of various nutrient limitations on fatty-acid production by Rhodotorula glutinis. Applied Microbiology and Biotechnology 38 (6), 784-789.

Hasslacher, M., Ivessa, A.S., Paltauf, F., Kohlwein, S.D., 1993. Acetyl-coA carboxylase from yeast is an essential enzyme and is regulated by factors that control phospholipid-metabolism. Journal of Biological Chemistry 268 (15), 10946-10952.

Holdsworth, J.E., Veenhuis, M., Ratledge, C., 1988. Enzyme-activities in oleaginous yeasts accumulating and utilizing exogenous or endogenous lipids. Journal of General Microbiology 134, 2907-2915.

Il'chenko, A.P., Shishkanova, N.V., Chernyavskaya, O.G., Finogenova, T.V., 1998. Oxygen concentration as a factor controlling central metabolism and citric acid biosynthesis in the yeast Yarrowia lipolytica grown on ethanol. Microbiology 67 (3), 241-244.

Kamzolova, S.V., Shishkanova, N.V., Morgunov, I.G., Finogenova, T.V., 2003. Oxygen requirements for growth and citric acid production of Yarrowia lipolytica. FEMS Yeast Research 3 (2), 217-222.

Kasemets, K., Drews, M., Nisamedtinov, I., Adamberg, K., Paalme, T., 2003. Modification of A-stat for the characterization of microorganisms. Journal of Microbiological Methods 55 (1), 187-200.

Kohda, T.A., Tanaka, K., Konomi, M., Sato, M., Osumi, M., Yamamoto, M., 2007. Fission yeast autophagy induced by nitrogen starvation generates a nitrogen source that drives adaptation processes. Genes to Cells 12 (2), 155-170.

Lanciotti, R., Gianotti, A., Baldi, D., Angrisani, R., Suzzi, G., Mastrocola, D., Guerzoni, M.E., 2005. Use of Yarrowia lipolytica strains for the treatment of olive mill wastewater. Bioresource Technology 96 (3), 317-322.

Mishina, M., Kamiryo, T., Numa, S., 1971. Acetyl-CoA carboxylase from Candida lipolytica. Methods in Enzymology 71, 37-39.

Moeller, L., Strehlitz, B., Aurich, A., Zehnsdorf, A., Bley, T., 2007. Optimization of citric acid production from glucose by Yarrowia lipolytica. Engineering in Life Sciences 7 (5), 504-511.

Mullinax, T.R., Mock, J.N., Harrison, J.H., 1982. Regulation of malate dehydrogenase activity by citrate. Federation Proceedings 41 (4), 1141.

Madzak, C., Gaillardin, C., Beckerich, J.M., 2004. Heterologous protein expression and secretion in the non-conventional yeast Yarrowia lipolytica: a review. Journal of Biotechnology 109 (1/2), 63-81.

Nicaud, J.M., Madzak, C., van den Broek, P., Gysler, C., Duboc, P., Niederberger, P., Gaillardin, C., 2002. Protein expression and secretion in the yeast Yarrowia lipolytica. FEMS Yeast Research 2 (3), 371-379.

Ochoa, S., 1955a. Malic dehydrogenase from pig heart. Methods in Enzymology 1 735-739.

Ochoa, S., 1955b. Malic enzyme. Methods in Enzymology 1, 739-753.

Onodera, J., Ohsumi, Y., 2005. Autophagy is required for maintenance of amino acid levels and protein synthesis under nitrogen starvation. Journal of Biologica Chemistry 280 (36), 31582-31586.

Paalme, T., Kahru, A., Elken, R., Vanatalu, K., Tiisma, K., Vilu, R., 1995. The computercontrolled continuous culture of Escherichia coli with smooth change of dilution rate (A-stat). Journal of Microbiological Methods 24 (2), 145-153.

Paalme, T., Elken, R., Vilu, R., Korhola, M., 1997. Growth efficiency of Saccharomyces cerevisiae on glucose/ethanol media with a smooth change in the dilution rate (A-stat). Enzyme and Microbial Technology 20 (3), 174-181.

Papanikolaou, S., Muniglia, L., Chevalot, I., Aggelis, G., Marc, I., 2002. Yarrowia lipolytica as a potential producer of citric acid from raw glycerol. Journal of Applied Microbiology 92 (4), 737-744

Papanikolaou, S., Aggelis, G., 2002. Lipid production by Yarrowia lipolytica growing on industrial glycerol in a single-stage continuous culture. Bioresource Technology $82(1), 43-49$

Papanikolaou, S., Muniglia, L., Chevalot, I., Aggelis, G., Marc, I., 2003. Accumulation of a cocoa-butter-like lipid by Yarrowia lipolytica cultivated on agro-industrial residues. Current Microbiology 46 (2), 124-130.

Papanikolaou, S., Galiotou-Panayotou, M., Chevalot, I., Komaitis, M., Marc, I., Aggelis G., 2006. Influence of glucose and saturated free-fatty acid mixtures on citric acid and lipid production by Yarrowia lipolytica. Current Microbiology 52 (2), 134-142.

Papanikolaou, S., Aggelis, G., 2011. Lipids of oleaginous yeasts. Part II: technology and potential applications. European Journal of Lipid Science and Technology 113, 1052-1073.

Poilpre, E., Tronquit, D., Goma, G., Guillou, V., 2002. On-line estimation of biomass concentration during transient growth on yeast chemostat culture using light reflectance. Biotechnology Letters 24 (24), 2075-2081.

Ratledge, C., Wynn, J.P., 2002. The biochemistry and molecular biology of lipid accumulation in oleaginous microorganisms. Advances in Applied Microbiology 51, $1-51$

Rattray, J.B.M., Schibeci, A., Kidby, D.K., 1975. Lipids of yeasts. Bacteriological Reviews 39 (3), 197-231.

Rymowicz, W., Rywinska, A., Zarowska, B., 2007. Biosynthesis of citric acid from crude glycerol by Yarrowia lipolytica in repeated-batch cultivations. Journal of Biotechnology 131 (2), S149-S150. 
Sattur, A.P., Karanth, N.G., 1989. Production of microbial lipids 3. Influence of C/N ratio - experimental-observations. Biotechnology and Bioengineering 34 (6), $872-874$

Sinigaglia, M., Lanciotti, R., Guerzoni, M.E., 1994. Biochemical and physiologicalcharacteristics of Yarrowia lipolytica strains in relation to isolation source. Canadian Journal of Microbiology 40 (1), 54-59.

Srere, P.A., 1962. Citrate-cleavage enzyme. Methods in Enzymology 5, 641-644.

Srere, P.A., Lipmann, F., 1953. An enzymatic reaction between citrate, adenosine triphosphate and coenzyme A. Journal of the American Chemical Society 75 (19), 4874.

Tai, M., Stephanopoulos, G., 2013. Engineering the push and pull of lipid biosynthesis in oleaginous yeast Yarrowia lipolytica for biofuel production. Metabolic Engineering 15, 1-9.

Volpe, J.J., Vagelos, P.R., 1976. Mechanisms and regulation of biosynthesis of saturated fatty-acids. Physiological Reviews 56 (2), 339-417.

Waite, M., Wakil, S.J., 1962. Studies on mechanism of fatty acid synthesis 12. Acetyl coenzyme A carboxylase. Journal of Biological Chemistry 237 (9), 2750 .
Workman, M., Holt, P., Thykaer, J., 2013. Comparing cellular performance of Yarrowia lipolytica during growth on glucose and glycerol in submerged cultivations. AMB Express 3, 58-66.

Wynn, J.P., Kendrick, A., Ratledge, C., 1997. Sesamol as an inhibitor of growth and lipid metabolism in Mucor circinelloides via its action on malic enzyme. Lipids 32 (6), 605-610.

Wynn, J.P., Ratledge, C., 1997. Malic enzyme is a major source of NADPH for lipid accumulation by Aspergillus nidulans. Microbiology 143, 253-257.

Yalcin, H.T., Ucar, F.B., 2009. Isolation and characterization of cheese spoiler yeast isolated from Turkish white cheeses. Annals of Microbiology 59 (3), 477-483.

Zhang, Y., Adams, I.P., Ratledge, C., 2007. Malic enzyme: the controlling activity for lipid production? Overexpression of malic enzyme in Mucor circinelloides leads to a 2.5-fold increase in lipid accumulation. Microbiology (SGM) 153, 2013-2025.

Zhang, H., Zhang, L., Chen, H., Chen, Y.Q., Ratledge, C., Song, Y., Chen, W., 2013. Regulatory properties of malic enzyme in the oleaginous yeast, Yarrowia lipolytica, and its non-involvement in lipid accumulation. Biotechnology Letters 35 (12) 2091-2098. 